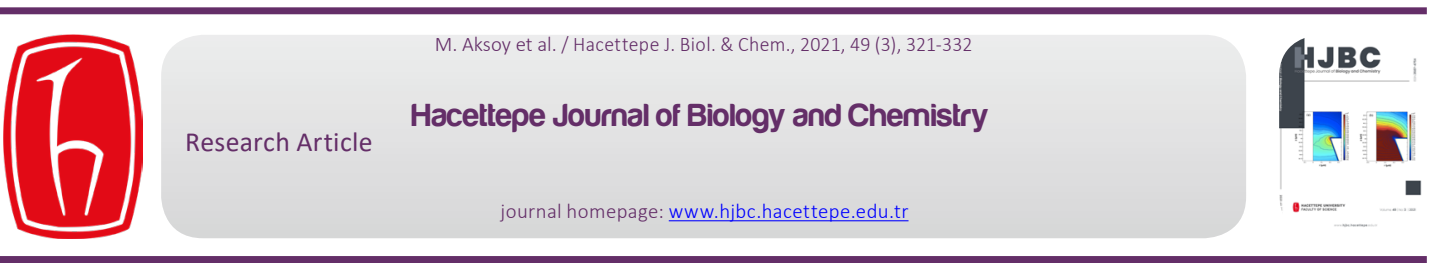

\title{
A Forward Genetic Screen For Isolation Of Fusion Defective Mating Type Minus Mutants In Chlamydomonas reinhardtii
}

\section{Chlamydomonas reinhardtii Eksi Eşey Tipinde Füzyon Kapasitesini Keybetmiş Mutant İzolasyonu İçin Bir ileri Genetik Tarama}

\author{
Münevver Aksoy ${ }^{1,2}$, Tammy T. La ${ }^{1,3},{\text { Nuenyan } \text { Lam }^{1 \oplus} \text {, and Charlene L. Forest }}^{1 \odot}$ \\ ${ }^{1}$ Department of Biology, Brooklyn College of CUNY, Brooklyn NY, USA. \\ ${ }^{2}$ Department of Agricultural Biotechnology, Akdeniz University, Antalya, Turkey. \\ ${ }^{3}$ Pfizer Inc., USA.
}

\section{ABSTRACT}

any biological processes require cell fusion, therefore defects in cell fusion result in many diseases. The unicellular Vreen alga Chlamydomonas reinhardtii is an excellent model organism to study cell-cell fusion. The objective of this study was to identify genes that are involved in C. reinhardtii mating type minus (MT-) gamete fusion. A forward genetics approach was taken in our work. We created several MT- fusion defective mutants using DNA insertional mutagenesis. These mutants were normal in the early stages of mating; they agglutinated with mating type plus $\left(\mathrm{MT}^{+}\right)$, removed their walls, adhered to their mating partner through their mating structures, but the cells did not fuse, indicating that the DNA insertional mutants were defective in the latest stages of fusion. The number of insertions was confirmed by Southern blots. Mutant J1 had one insertion and the flanking genomic DNA was cloned by TAIL-PCR and RESDA-PCR. The insertion is in a gene predicted to be involved in 5-deoxystrigol biosynthesis.

\section{Key Words}

Chlamydomonas reinhardtii, mating type minus, fusion defective mutant, forward genetics screen.

\section{ÖZ}

\begin{abstract}
Birçok biyolojik proses için hücre füzyonu gereklidir, bu yüzden hücre fuzyonu eksikliğinde birçok hastalık görülur. Tek hücreli yeşil alg Chlamydomonas reinhardtii hücre fuzyonu araştırmaları iç mükemmel bir model organizmadır. Bu çalışmanın amacı C. reinhardtii eksi eşey tipinde (MT-) gamet füzyonunda rol alan genlerin belirlenmesidir. Çalışmada ileri genetik tarama (forward genetics) yöntemi kullanılmıştır. DNA insersiyonel mutagenez yöntemi kullanılarak füzyon kapasitesini yitirmiş MT- mutantlar elde edilmiştir. Bu mutantlar çiftleşmenin erken evrelerinde normal aktivite göstermişlerdir; artı eşey tipi $\left(M T^{+}\right)$ile aglütinasyon göstermişler, hücre duvarlarını çıkartmışlar, karşı eşey tip ile adhezyon yapmışlar fakat hücreler füzyon yapamamışlardır, bu da DNA insersiyonel mutantlarının füzyonun en geç evrelerinde fonksiyon eksikliği taşıdığını göstermistir. DNA insersiyon sayısı Southern blot ile belirlenmiştir. J1 mutantında bir insersiyon görülmüş ve insersiyona komşu genomic DNA bölgesi TAIL-PCR ve RESDA-PCR ile klonlanmıştır. Insersiyonun 5-deoxystrigol biyosentezinde görev alması muhtemel bir gende olduğu belirlenmistir.
\end{abstract}

\section{Anahtar Kelimeler}

Chlamydomonas reinhardtii, eksi eşey tipi, füzyon kapasitesini kaybetmiş mutant, ileri genetik tarama.

Article History: Received: Feb 14, 2020; Revised: Dec 24, 2020; Accepted: Feb 6, 2021; Available Online: May 7, 2021.

DOI: https://doi.org/10.15671/hjbc.689397

Correspondence to: M. Aksoy, Department of Agricultural Biotechnology, Akdeniz University, Antalya, Turkey.

E-Mail: maksoy@akdeniz.edu.tr 


\section{INTRODUCTION}

Cell-cell fusion is involved in many biological processes; fertilization, formation of multinucleated muscle syncytia, development of bone and placenta, the immune response, tumorigenesis, and stem cell mediated tissue regeneration [1]. In spite of the diversity of cell types that undergo fusion, the process of cell fusion, including cell-cell adhesion, alignment and membrane mixing are common in every cell type.

Chlamydomonas reinhardtii is a unicellular, biflagellated, eukaryotic green alga that is a model organism used to study diverse cellular processes; cell cycle, photosynthesis, cilia function among many others $[2,3]$. It is approximately $10 \mu \mathrm{m}$ long. Most of its life cycle is in the vegetative haploid stage. When deprived of nitrogen, simply by placing cells in nitrogen free medium in the laboratory, they go through gametogenesis and become mating competent [4]. The gametes demonstrate differences from the vegetative cells they are derived from. Gametes fuse to form a diploid zygote, which can stay dormant for months when kept in the dark. When the environmental conditions are normal and in the presence of light, a zygote undergoes meiosis and forms four or eight haploid progeny. The mating reaction of $C$. reinhardtii is a useful system for understanding the nature of gamete fusion (fertilization). There are two mating types (sexes): mating type plus $\left(M T^{+}\right)$and mating type minus (MT-). Mating type is determined by the mating type (MT) locus, which is located on the left arm of linkage group (chromosome) VI. The genes that are found in this locus determine if the cells will mate as $M T$ - or $\mathrm{MT}^{+}$. The MT locus is under recombinational repression to assure that $m t$-linked genes are segregated together. The haploid progeny maintain their type without any mating type switching.

When the gametes of opposite mating types are mixed together, they recognize each other by glycoproteins called agglutinins found on the flagellar surface [5]. Plus agglutinin is encoded by SAG1 and minus agglutinin is encoded by SAD1. SAG1 is unlinked to the MT locus, but $S A D 1$ is located in the MT locus $[6,7]$. SAD1 is also found in $M T^{+}$but not expressed, because its expression requires the MID gene (Minus Dominance) which is only found in the MT- locus [6].
After recognition, agglutination occurs and the flagella undergo tipping, a preference for interaction at the tips $[8,9]$. This leads to a series of signaling events. It was suggested that transmission of the sexual signal is mediated by calcium fluxes across the flagellar membrane [10]. Flagellar interactions initiate a protein-kinase dependent signaling pathway that leads to activation of a gamete specific adenylyl cyclase. This leads to a rapid increase in the intracellular CAMP concentration [11]. Signaling results in secretion of a serine protease required to convert a periplasmic prometalloprotease to an active matrix degrading metalloprotease (autolysin) $[12,13]$. This release leads to degradation of the cell wall [14]. Signaling also leads to activation of mating structures [15]. The mating structures are located next to one of the flagella in both mating types. The activated $\mathrm{MT}^{+}$mating structure is a long microfilament filled, acrosome like extension [15]. At the tip of $\mathrm{MT}^{+}$, there is a glycoprotein layer called fringe [16]. Activation of the MT- mating structure results in a slight elevation of the plasma membrane (a dome like structure) [17]. Cells mobilize membrane particles to the center of the mating structure, which was cleared of particles during gametogenesis $[16,18]$. The tip of the $\mathrm{MT}^{+}$mating structure recognizes and adheres to the activated MT- mating structure [17]. This was first shown by the gam mutants [19]. The genetic locus of this gene has not yet been identified. The $\mathrm{MT}^{+}$structure "fringe" is made of FUS protein that is involved in adhesion to the MTstructure $[20,21]$. On the MT- structure, GCS1 (Generative Cell Specific 1) has been identified [22]. The gene, now called HAP2/GCS1 was originally identified in lily and found to have a homologue in $C$. reinhardtii. It is a transmembrane protein that localizes to the MT- structure [23]. Its expression is low in vegetative cells of both mating type but increased in MT- gametes. Once adhesion and fusion of the mating structures occur, the tubule rapidly shortens and brings the apical ends of the cells into opposition [24]. This adhesion results in gamete fusion and production of the diploid quadriflagellated cell (QFC), or zygote. After a few hours, the zygote resorbs its flagella and forms a thick zygospore wall. Following maturation in dark (for a minimum of 6 days), the zygote germinates upon returning to light, undergoes meiosis and forms four or eight haploid progeny. 
Our goal is to identify the genes that are involved in gamete fusion in C. reinhardtii. All the fusion defective $\mathrm{MT}^{+}$mutants are known to be defective in mating structure adhesion, and MT-fusion defective mutants are known to adhere but do not fuse [19]. Our hypothesis is that there are at least two proteins on the MT- mating structure that are required for fusion to occur (the GAM gene product and HAP2/GCS1 gene product). We therefore did a forward genetic screen with the goal to isolate fusion defective MT- mutants defective in the late stages of mating and to identify the genes that are being disrupted. We isolated nine fusion defective mutants in five independent screens and plan to identify the function of the genes that were interrupted in each mutant in our future studies. We were able to locate the insertion site in a mutant we called $\mathrm{J} 1$; insertion is in a gene that is involved in strigol biosynthesis. We plan to determine the exact function of this gene in the gamete fusion process in our future work.

\section{MATERIALS and METHODS}

\section{C. reinhardtii Cell Strains and Media}

The wild type strains used were CC-620 R3 MN MT (wild type, mating type +) and CC-621 NO MT- (wild type, mating type -). The streptomycin resistant strain $C$. reinhardtii CC-275 (sr-u-2-23, MT-) was used for mutagenesis as parental strain. Media were prepared according to the recipes of Chlamydomonas Culture Collection (http://www.chlamy.org).

\section{Insertional Mutagenesis and pSP124S}

The sr-u-2-23 MT- strain was used to create fusion defective insertional mutants [25]. This technique creates random insertional mutants $[26,27]$ using the ble plasmid as described in Lumbreras et al. (1998) [28]. Cells of sr-u-2-23 MT- were grown in $100 \mathrm{ml}$ TAP medium in a $250 \mathrm{ml}$ Erlenmeyer flask for two days under bright light on a New Brunswick gyrotatory shaker. After two days, a small volume of cells (1- $10 \mathrm{ml}$, depending on concentration) was inoculated into $400 \mathrm{ml}$ of TAP medium in a $1000 \mathrm{ml}$ flask. After inoculation, the color of the culture was pale green. Cells were grown two more days at the same conditions, to mid-log phase $\left(1-2 \times 10^{6}\right.$ cells $/$ $\mathrm{ml})$. Before transformation, the cell concentration was determined by removing $1 \mathrm{ml}$ of liquid from the flask and counting the cells using a hemocytometer. For each transformation $6 \times 10^{7}$ log phase cells were transferred into sterile $200 \mathrm{ml}$ Nalgene centrifuge bottles and centrifuged at 5000 rpm for 5 minutes using a Sorvall Su- perspeed RC2-B centrifuge. After centrifugation, the supernatant was discarded, thawed autolysin was added, and cells were incubated with the autolysin for 45 minutes at $32^{\circ} \mathrm{C}$ in two $50 \mathrm{ml}$ sterile Nalgene Oak Ridge centrifuge tubes. Cells were checked under the microscope to make sure the autolysin has degraded the cell walls (when the walls are removed, cells become round and swim more slowly). After incubation, the cells were centrifuged at 5000 rpm for 5 minutes. The autolysin was discarded and $300 \mu \mathrm{l}$ of TAP medium was added for each transformation. Cells were transferred to Falcon $5 \mathrm{ml}$ polystyrene round bottom tubes, each containing 0.3 grams of $0.4 \mathrm{~mm}$ sterile glass beads (Thomas). The beads had been sterilized in a $220^{\circ} \mathrm{C}$ incubator for 2 hours prior to the experiment. $1 \mu \mathrm{g}$ of BamHI digested pSP124S $[28,29]$ was added to the tubes and the suspension was vortexed at top speed for 20 seconds using a Scientific Industries Vortex-Genie K- 550-G mixer. After vortexing, the cells were transferred to $20 \mathrm{ml}$ of TAP medium and left under light for 18 hours for recovery and expression of the ble gene. The next day, the cells were centrifuged and plated on TAP agar plates containing $15 \mu \mathrm{g} / \mathrm{ml}$ Zeocin $^{\mathrm{TM}}$ (Invitrogen) to select transformed colonies. The transformants appeared after 7 to 10 days.

\section{Selection for Fusion Defective Mutants by the Streptomycin Selection Method}

CC-275, the sr-u-2-23 MT- strain, was used for mutagenesis. This strain has the sr2 mutation, a uniparentally inherited gene for resistance to $50-500 \mathrm{~g} / \mathrm{ml}$ of streptomycin sulfate and has a high mating efficiency when mated with the opposite mating type. Following mutagenesis, the streptomycin selection technique [25] was used to select for MT-mutants. When wild type $\left(M T^{+}\right)$ and sr2 (MT-) gametes are mated, all of the zygotes show the $\mathrm{MT}^{+}$characteristic, sensitivity to streptomycin, within a short time after gamete fusion [30]. Inheritance of the sr2 mutation does not follow Mendelian patterns because this gene is located on the chloroplast DNA. This resistance gene is usually only inherited through $M T^{+}$parental cells. After the mating of wild type $\left(M T^{+}\right)$ and sr-u-2-23 $M T$-, all the zygotes and wt $M T^{+}$cells will die; only MT- gametes which did not mate will survive. Thus, unmated $s r-u-2-23$ MT-gametes can be selected with this procedure. 
A

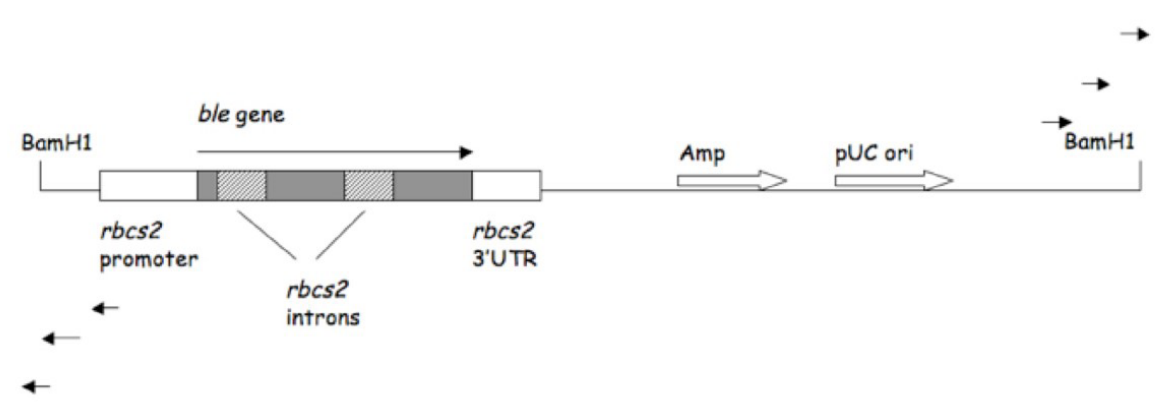

B

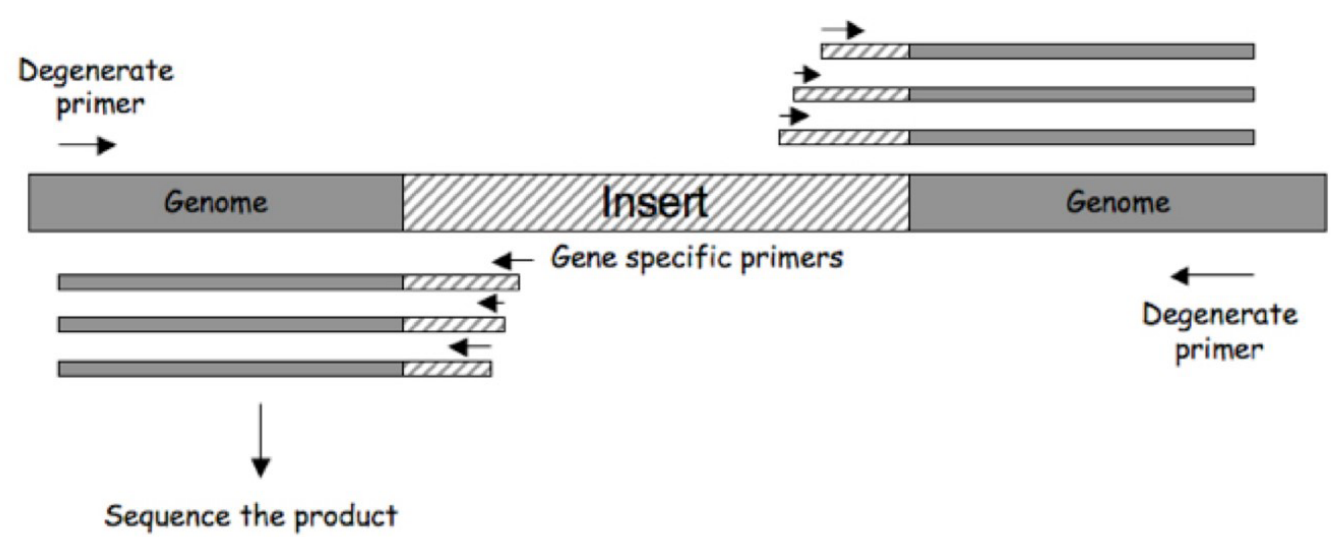

Figure 1. Schematic Description of TAIL-PCR and RESDA-PCR. A. Diagram of BamHI digested PSP124S which was used in insertional mutagenesis. The possible insertion into the genome and position of gene specific primers at the $5^{\prime}$ and $3^{\prime}$ end of the plasmid are shown with arrows. B. Mechanism of TAIL-PCR and RESDA-PCR. Gene specific and degenerate primers (bind to genome) produce more specific product after each nested PCR, a smaller product is produced after each reaction. The final specific product is then sent for sequencing to determine the flanking genomic region of the insertion site.

To select for fusion defective mutants, transformed Zeocin ${ }^{\mathrm{TM}}$-resistant $s r-u-2-23$ MT- cells were grown on $50 \mathrm{\mu g} / \mathrm{ml}$ streptomycin agar plates to maintain their resistance. After 12- 15 days of growth (keeping cells on these plates for more than 9 days allows them to form plate gametes) the plates were flooded with SEM-N medium [31] for 2-3 hours to allow the cells to develop flagella and swim up. Cells were taken off the plates and then mated with wt $M T^{+}$gametes for 12-16 hours. After mating, the zygotes form a pellicle on the surface of the medium. The mating mixture was filtered with a sterile $10 \mu \mathrm{m}$ pore diameter filter to remove these zygote clumps. The filtrate contains the un-mated $s r-u-2-23$ $M T$ - and wt $M T^{+}$cells. $10 \mu \mathrm{l}$ to $100 \mu \mathrm{l}$ of the filtrate were plated on $200 \mu \mathrm{g} / \mathrm{ml}$ streptomycin plates. In some cases, a 1:10 dilution of the filtrate was plated if the mating was not good. If a large zygote pellicle was formed, this meant mating was efficient and dilution was not necessary. Plates were placed under light for 10 days to allow streptomycin resistant colonies to grow.

\section{Mutant Screening}

After the selection, the colonies that grew on streptomycin plates were picked and transferred onto TAP plates for further growth. 16-32 clones were picked from each selection plate. After about 6-7 days on the TAP plates, cells were inoculated into liquid $\mathrm{N}$-free medium for 16 hours and mated with $\mathrm{MT}^{+}$. The clones that formed pellicles were eliminated. The ones that did not form a pellet were retested. Each clone was resuspended in about $200 \mu \mathrm{l}$ of SEM-N and kept under lights for 16 hours to induce gametogenesis. After gametogenesis, each clone was checked for its motility and agglutination with $M T^{+}$. Clones that agglutinate but do not fuse with $M T^{+}$were saved for further study. 


\section{Determination of BFC's, Pairs and Groups in the Mutants}

Pair and group formation results from mating structure adhesion in mutants that cannot fuse [19]. Therefore, we can differentiate between adhesion defective and fusion defective mutants by determining if they can form pairs and groups. To do this analysis, the mutants were kept in N-free liquid medium [31] for 16 hours, mated with $\mathrm{MT}^{+}$for different durations and fixed with $3 \%$ glutaraldehyde in $10 \mathrm{mM}$ HEPES buffer. The next day, the glutaraldehyde was removed, the cells were washed twice with HEPES buffer and resuspended in HEPES buffer in the original mating volume [19]. Cells were observed under a phase-contrast microscope for BFC (biflagellate cells or gametes), QFC (quadriflagellated cells or zygotes), pairs and groups (gametes attached via their mating structures). When mutants that are capable of mating structure adhesion but not fusion are mated with the opposite mating type and treated with IKI or glutaraldehyde, the large groups of gametes participating in flagellar agglutination are disrupted. However, the gametes adhering by their mating structures have been shown to form stable pairs and groups that are not disrupted by these treatments [17].

\section{Genomic DNA Isolation and Southern Blot Analysis}

DNA was isolated with the Qiagen Plant Mini Kit or by the phenol-chloroform method [32]. $10 \mu \mathrm{g}$ of genomic DNA isolated from the mutants and the parent strain used for mutagenesis (sr-u-2-23 MT-) was digested with Kpnl, ethanol precipitated and dissolved in $30 \mu \mathrm{l}$ TE. Digested DNA was run on a $1 \%$ agarose gel for $4-5$ hours by applying 40-50 V. The gel was then subjected to two 15 minute washes in alkaline transfer buffer $(0.4 \mathrm{~N} \mathrm{NaOH}, 1 \mathrm{M} \mathrm{NaCl})$ at room temperature by gentle agitation and transferred to a positively charged nylon membrane (Roche). pSP124S was used as the template for PCR to generate the ble probe for Southern blotting. The primers used were named bleforward (5'-atggccaagctgaccagc- $\left.3^{\prime}\right)$ and blereverse (5'-ggtcgacgtcggttagtc- $\left.3^{\prime}\right)$. These primers produce a 538 bp product. The radioactive labeling method using the RadPrime DNALabeling System (Invitrogen) was used for labeling. The efficiency of labeling was determined with a Scintillation Counter (Technical Association Surface Monitor Model TBM-15). The membrane was exposed to X-Ray film for 2 hours or exposed to a phosphorimager.

\section{Sequencing the Flanking Genomic Region of the Insertion}

\section{TAIL-PCR and RESDA-PCR}

TAIL-PCR (Thermal Asymmetric Interlaced PCR) [33] and RESDA-PCR (Restriction Enzyme Site-Directed Amplification PCR) [34] were used to sequence the flanking genomic regions of the insertions in the mutants. Primers designed for the insert (gene specific primers) and degenerate primers that bind to the genomic DNA were used to amplify the flanking regions of the insertions. Schematic representation of PSP124 and TAIL-PCR and RESDA-PCR is shown in Figure $1 A$ and $1 B$, respectively.

Table 1. List of primers used in TAIL-PCR and RESDA-PCR.

\begin{tabular}{|c|c|}
\hline Primer Name & Sequence \\
\hline \multicolumn{2}{|c|}{ Degenerate Primers } \\
\hline RD 227 & 5'-NTCGWGWTSCNAGC-3' \\
\hline Eco721 & 5'-CCAGTGAGCAGAGTGACGIIIINNSCACGTGS-3' \\
\hline Q0* & 5'-CCAGTGAGCAGAGTGACG-3' \\
\hline \multicolumn{2}{|c|}{ Gene Specific Primers } \\
\hline Ble1 & 5'-TGTTGTCCGGCACCACCTGGTC-3' \\
\hline Ble2 & 5'-CTGATGAACAGGGTCACGTC-3' \\
\hline BleC & 5'-AGATGTTGAGTGACTTCTCTT-3' \\
\hline RD223 & 5'-TTGGCTGCGCTCCTTCTGGCATTTAAATC-3' \\
\hline RD224 & 5'-GCATTTAAATCTCGAGGTCGAC-3' \\
\hline RD225 & 5'-GATAAGCTTGATATCGAATTCC-3' \\
\hline
\end{tabular}

*QO is not degenerate, but it is used in pair with gene specific primers. $\mathrm{N}$ : any nucleotide, W: A or T, S: G or C, I: inosine. 
0.5-1 $\mu$ g of undigested genomic DNA was used as the template for the primary PCR reaction. The product of the primary PCR is diluted $1: 10$ to $1: 25$, depending on the amount of the product, and used as the template for the secondary PCR reaction along with nested gene specific primer and degenerate primer for TAIL-PCR; in RESDA-PCR, primer QO (same sequence as the $5^{\prime}$ end of degenerate primers used in the primary reaction) was used in the secondary and tertiary PCR. After secondary PCR, tertiary and sometimes additional nested PCRs were done until the product became specific enough (no smear, clear band) so it could be gel purified and sequenced. In some cases, if there was not a single band produced after tertiary PCR, a band that was thought to be the most specific was cut out of the gel, purified and the sample was used as the template for the following nested PCRs.

The degenerate primers used in TAIL-PCR are completely degenerate, whereas in RESDA-PCR the primers are partially degenerate. RESDA-PCR primers have restriction site sequences and a limited number of degenerate sequences at the $3^{\prime}$ end to allow the primer to bind at various restriction sites in the genome. This $3^{\prime}$ region is connected to the $5^{\prime}$ end, which has a fixed sequence, by several inosine bases which also give a more degenerate characteristic to the primer. The $5^{\prime}$ fixed sequence was used in the following nested PCR after doing the first round of PCR to get a specific product. The list of primers is shown in Table 1.

\section{Genome Walking from the Insertion}

Primers J1-F (5'-CAGTGCTGACCCCCACTATT-3') and RD225 (5'- GATAAGCTTGATATCGAATTCC-3') were used for walking into the genome from the $\mathrm{J} 1$ insertion site.

\section{Determining if there is a Possible Deletion in the In-} sertion Region of $\mathrm{J} 1$

Primers J1-F (5'- cagtgctgacccccactatt-3') and J1-R (5'- cttcacgtcaactccccatt-3') were used to amplify genomic DNA upstream of the insertion point. Primers j1-f2 (5'- CGTTGAACATAGCGACCTCA-3') and j1-r2 (5'CCTGCATCGCATACACTGTC-3') were used to amplify the downstream region of the insertion. Primers j1-f3 (5'CATCACGACCCTCATGTTTG-3') and j1-r3 (5'- GGCAGGACAGATAGGAGCAG- 3') were used to amplify a region of the downstream gene model Cre16.g661200.

\section{Scanning Electron Microscopy}

For SEM analysis a JEOL JSM 6300F model was used in the Brooklyn College Physics Department.

\section{Dehydration and Critical Point Drying}

Cells were mated for 15-20 minutes and fixed with 1:1 volume of $3 \%$ glutaraldehyde in $10 \mathrm{mM}$ HEPES, $\mathrm{pH} 7$, overnight at $4^{\circ} \mathrm{C}$. The next day, the glutaraldehyde was removed, the cells were washed twice with HEPES buffer and resuspended in the original volume of HEPES. During the washes, the cells were centrifuged at a low speed to prevent breaking of the pairs.

Table 2. List of mutants isolated in the screen.

\begin{tabular}{|c|c|c|c|}
\hline & MUTANT & PAIR FORMATION & FUSION \\
\hline $\begin{array}{l}\text { Group 1. Non-agglutinating } \\
\text { MT- }\end{array}$ & $7-26$ & ND & Fuses after cAMP treatment \\
\hline Group 2. Fusion- defective MT- & $\begin{array}{c}5 \\
45 \\
\mathrm{~A} 2^{*} \\
1-18^{*} \\
1-23^{*} \\
1-25^{*} \\
1-35^{*} \\
2-8^{* *} \\
2-29^{* *} \\
\mathrm{~J} 1\end{array}$ & Yes & No \\
\hline $\begin{array}{l}\text { Group 3. Mating Type Switch } \\
\text { (agglutinates with MT-) }\end{array}$ & $\mathrm{cl}-1$ & ND & No \\
\hline
\end{tabular}

\footnotetext{
* Five isolates from the same experiment. ${ }^{* *}$ Two isolates from the same experiment. ND: Not determined.
} 
A

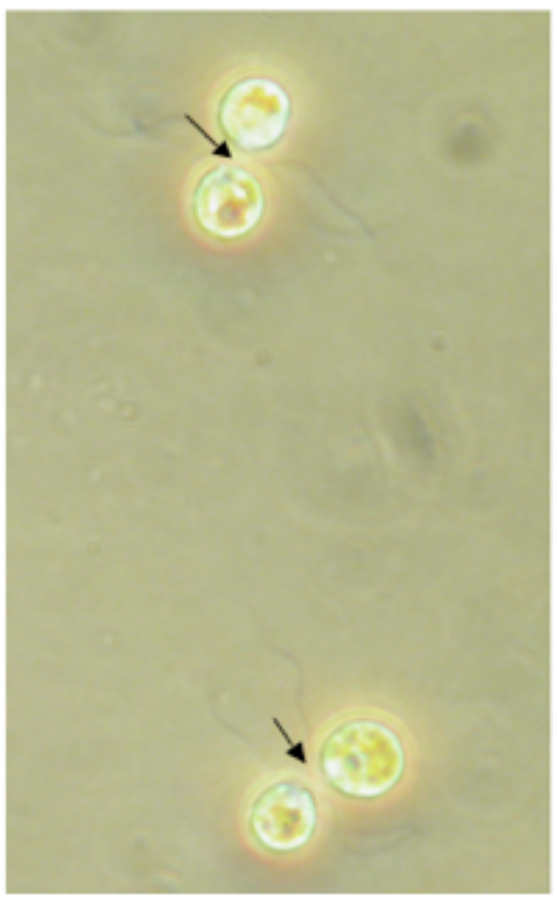

B

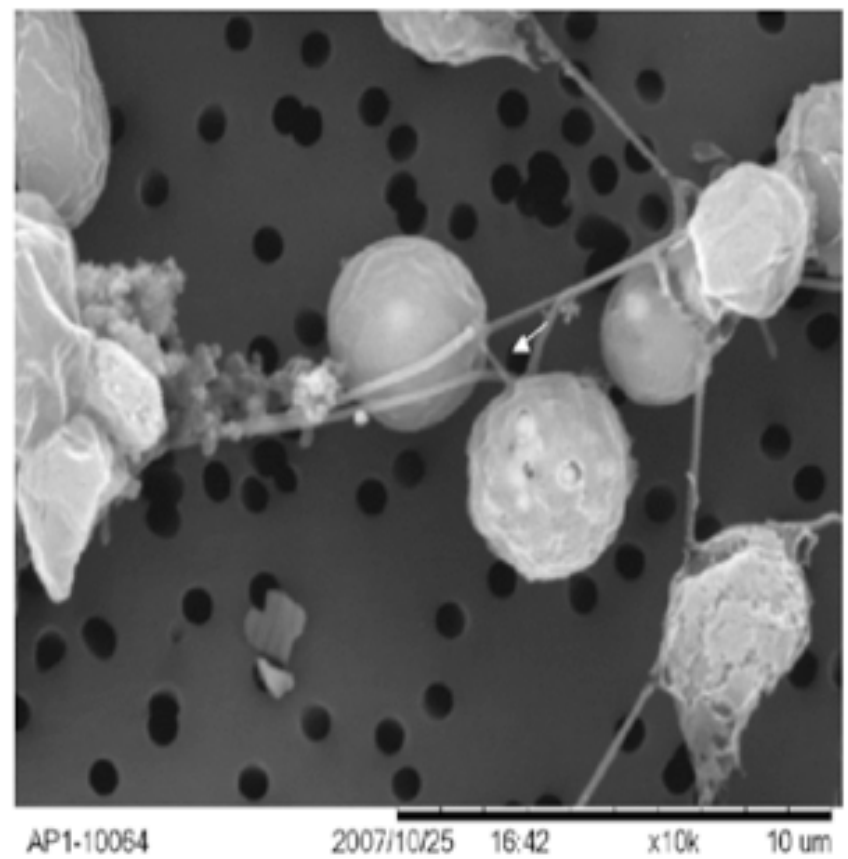

Figure 2. Mating structure adhesion in the J1 Mutant. A. Phase contrast image of adhering gamete pairs. Black arrows indicate the region where the mating structures adhere (mating structure can be seen in panel B, shown with white arrow). B. SEM image showing the mating structure adhesion in a pair of gametes. The white arrow points to the attachment between the two gametes.

\section{Dehydration}

Cells were dehydrated on Nuclepore filters $(13 \mathrm{~mm}$ diameter, $0.8 \mu \mathrm{m}$ pore size) in Millipore filter holders. 2-3 drops of fixed cells were dehydrated through $30 \%, 60 \%$, $90 \%$ and $100 \%$ ethanol washes. After these washes, the filters were removed from the filter holders in a Petri dish of $100 \%$ ethanol and wrapped in labeled aluminum foil packets with holes to allow exchange in the critical point dryer.

\section{Critical Point Drying}

Critical point drying of the samples was done in a Tousimis 790 critical point dryer.

\section{Sputter Coating of the Samples}

The samples were then coated with gold in a Hummer VI sputter coater.

\section{RESULTS}

\section{Mutants Generated}

All nuclear mutants were generated by DNA insertional mutagenesis using the glassbead transformation technique [26]. The plasmid pSP124S was used to transform the host strain CC 275. Following transformation, fusion-defective mutants were selected by the streptomycin selection procedure [25]. Because the streptomycin selection procedure used selects for all cells that cannot form zygotes, many non-agglutinating mutants were also isolated. Although non-agglutinating mutants were not the main concern of this study, some of them were kept for future studies. The list of the mutants generated is shown in Table 2. 


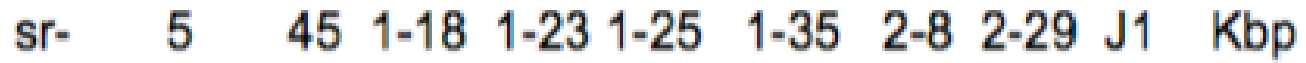

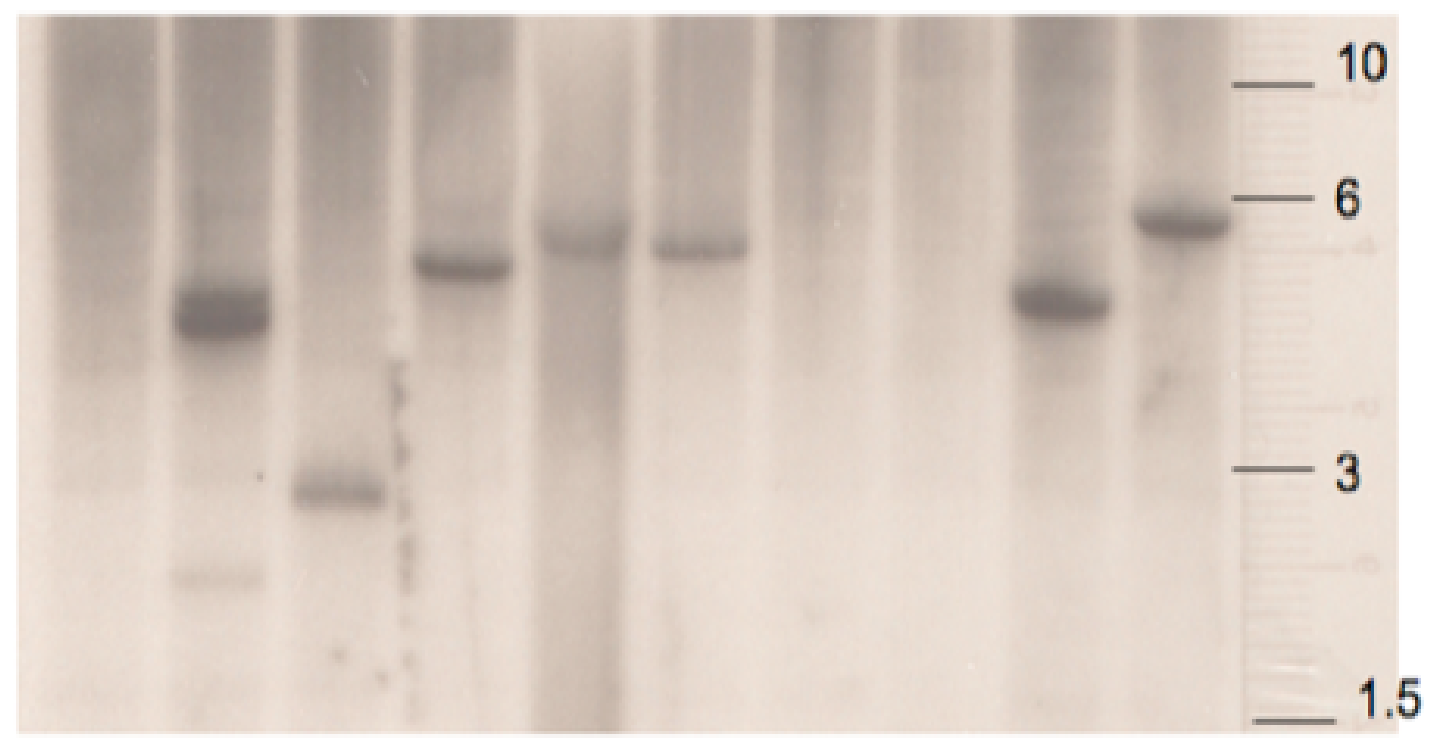

Figure 3. Southern blot results. The ble sequence was radioactively labeled and used as the probe. As expected sr- (Parental strain: sru-2-23 MT-) does not have any bands, mutants 45, 1-18, 1-23, 1-25, 2-29 and J1 have 1 insertion, whereas mutant 5 has 2 and possibly 3 insertions.

All of the mutants in group 2 showed the fusion-defective phenotype; capable of agglutination with mating type plus, but unable to fuse to form a zygote. This phenotype was confirmed for the $\mathrm{J} 1$ mutant using phase contrast microscopy (Figure 2A) and scanning electron microscopy (Figure 2B). Images show the mutants were able to form pairs and groups when mated with the wild type $\mathrm{MT}^{+}$(indicating that they can adhere by their mating structures but are unable to fuse).

\section{Sequencing the Flanking Region in Mutant J1 by RESDA-PCR}

According to Southern Blot results, the mutant J1 had only one insertion which may be responsible for the mutant phenotype (Figure 3). Cloning of the flanking regions of the insert was done to determine which gene(s) are disrupted by the insertion which might be the cause of the fusion defective phenotype.

\section{Primary PCR}

Genomic DNA of mutant J1 was used for cloning of the flanking regions by RESDA-PCR. Figure $4 A$ shows the primary PCR results for multiple mutants, including $J 1$ using the gene specific primer RD223 (which binds to rbcs 2 promoter) and the degenerate primer Eco721 (which binds to the genome wherever there is a cutting site for the Eco721 restriction enzyme). All samples show smears, which usually occurs for primary PCR.

\section{Secondary PCR}

Secondary PCR was performed using the primary PCR products as the template. In RESDA-PCR, the insert specific and degenerate primers used in the secondary PCR are both nested, to get more specific products. Primer RD224 and Q0 (the nested primers for degenerate primers used in primary PCR) were used. The priming site for RD224 is still in the rbcs2 promoter, but closer to the $5^{\prime}$-end. The result of the secondary PCR is shown in Figure 4B. While there are differences between the samples, no specific products were identified for any of the mutants. 

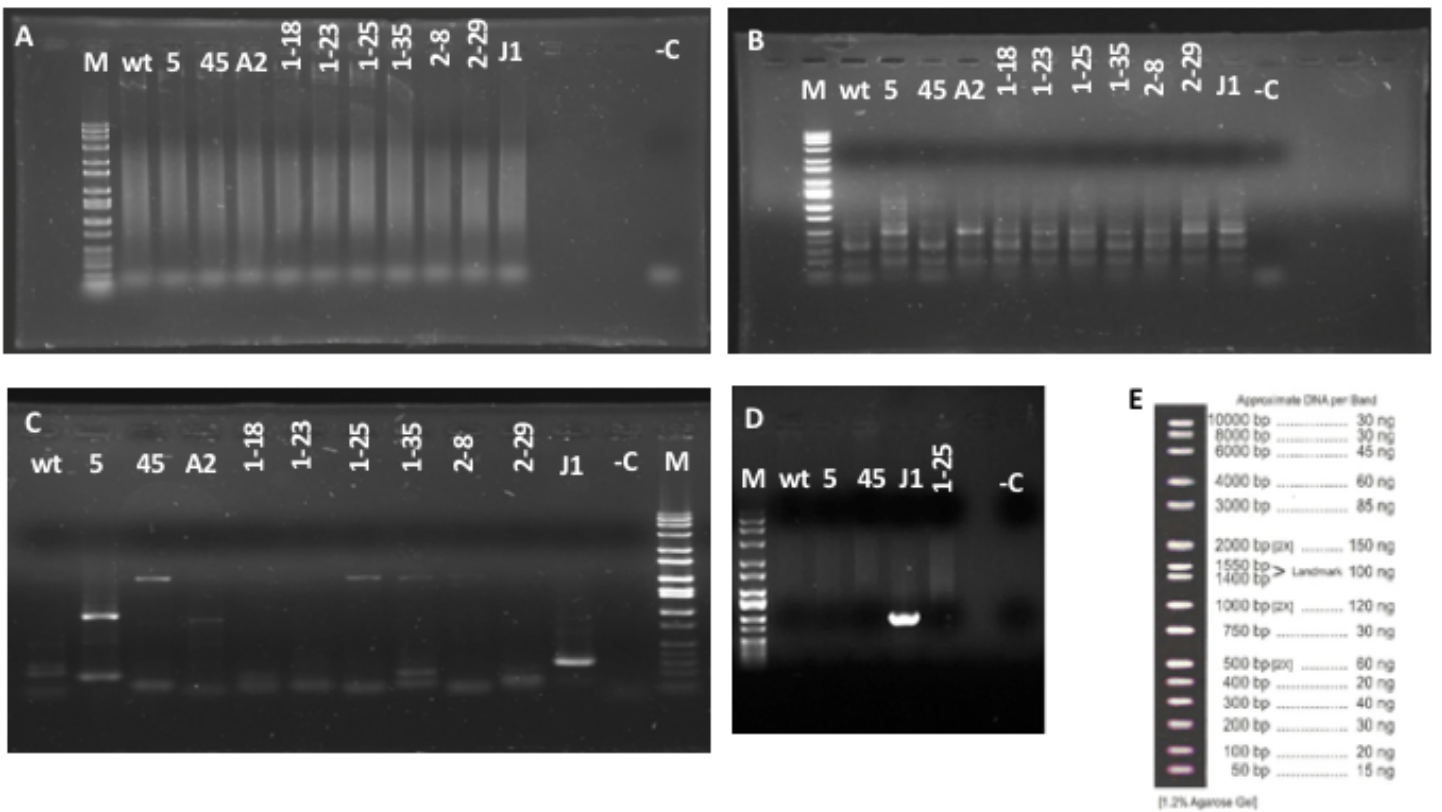

Figure 4. Sequencing the Flanking Region in J1 by RESDA-PCR. A. Primary RESDA-PCR results. B. Secondary RESDA-PCR results. C. Tertiary RESDA-PCR produces specific products which are sequenced. D. Genome walking for J1. Only J1 genomic DNA gave a PCR product as expected. E. DNA ladder used in the agarose gels. M: DNA size marker shown in panel E. wt: Wild type strain (sr-u-2-23 MT-) -C: Negative control (PCR without any DNA template).

\section{Tertiary PCR and Determination of the Insertion Site in Mutant J1}

The secondary PCR products were used as templates for the tertiary nested PCR. The primers were RD225 and Q0. The tertiary RESDA-PCR gave more specific products. This time a very specific single product was identified for the mutant J1 (Figure 4C). This band from mutant J1 was gel extracted and was sent, along with the primer RD225 for sequencing. From the sequencing a 225 bp read was obtained. This sequence was used to do a blast search in the Chlamydomonas genome database and a single match was obtained which matched a region in chromosome 16 . This region was in the gene model Cre16.g661150 which is predicted to be involved in 5-deoxystrigol biosynthesis.

\section{Walking into Genome from the Insertion}

To confirm that the plasmid pSP124S inserted into the genomic region of chromosome 16, primers were designed for chromosome 16 (primer J1-F) and PCR was performed with primers RD225 and J1-F. PCR of genomic DNA from mutant J1 generated a product of the expected size of $987 \mathrm{bp}$, confirming our tertiary PCR results that there is an insertion in this region (Figure 4D).

\section{Determining if there is a Possible Deletion in the In- sertion Region}

It is known that DNA insertional mutagenesis can result in large deletions when the insertion happens $[35,36]$. To test for intactness of the genomic region at the insertion site in chromosome 16, we performed diagnostic PCR for regions upstream and downstream from the insertion site. We know that the insertion occurred at position 2,526,627 bp of chromosome 16 and we were able to sequence the $225 \mathrm{bp}$ downstream of this insertion point. Figure 5A shows the PCR result from downstream of the insertion using primers J1-F and J1-R. These primers amplify a 661 bp product in chromosome 16; from intron 2 to intron 4 of gene model Cre16.g661150. All the strains, including $\mathrm{J} 1$ gave the right size product, indicating that the region upstream of the insertion site was intact. Figure 5B shows the PCR result from downstream of the insertion site. PCR was performed with primers j1-f2 and j1-r2. Again, all mutants gave the expected product (1782 bp); therefore, we can conclude that the downstream region adjacent to the insertion site was intact. We did PCR further downstream with primers j1-f3 and j1-r3. These primers amplify a 1362 bp region in the downstream gene model Cre16.g661200. The result of this PCR is not shown here, but we again got product for all the mutants. 
A

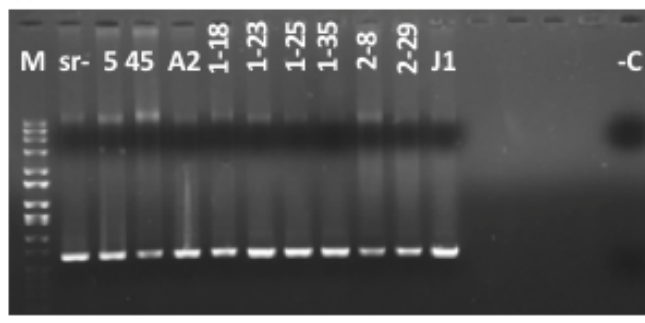

B

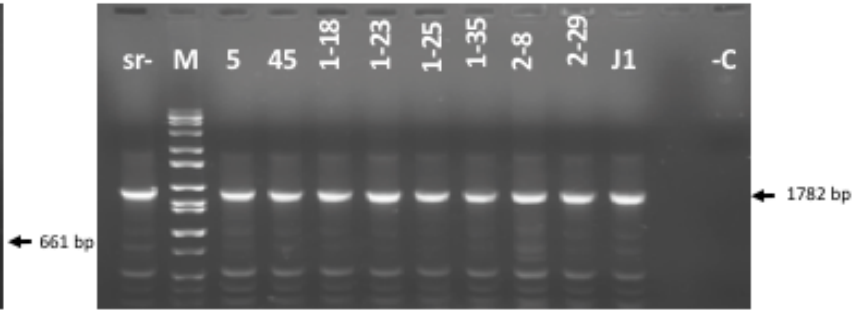

Figure 5. Determining if there is a deletion in the J1 insertion site. A. PCR for the region upstream of the insertion gave product for all of the mutants, including $\mathrm{J} 1$, indicating that there is no deletion. B. The region downstream of the insertion is also intact. M: DNA size marker shown in Fig. 4E. sr-: Parental strain (sr-u-2-23 MT-). -C: Negative control (PCR without any DNA template).

\section{DISCUSSION}

We applied forward genetics to identify genes that are involved in gamete fusion in MT- C. reinhardtii cells. Cells of the streptomycin resistant strain, sr-u-2-23 MT- were randomly mutagenized by DNA insertion of pSP124S. Ten fusion defective mutants were generated in 5 independent transformations (Table 1). We showed that all of the insertional mutants are able to recognize $\mathrm{MT}^{+}$cells, transmit signals, remove cell walls and adhere to $\mathrm{MT}^{+}$partners, suggesting that our mutants are blocked at the last stage of mating, fusion. We also isolated mutants that have defects in mating partner recognition, but those mutants were not the subject of this work. We believe they may have mutations in gamete differentiation or in agglutinin synthesis, a hypothesis we plan to test in the future. Further, a mating type switch mutant (clone-1) was isolated in which we think the insertion might have disrupted the MID gene whose function is to activate MT- gene expression and to repress $\mathrm{MT}^{+}$gene expression. Analysis of this mutation will be the subject of a future study.

We showed the insertion number for each of the fusion defective mutants by Southern blot analysis. According to our Southern blot results, Clone-5 has 2 or 3 insertions. All other mutants except 1-35 and 2-8 (which showed no bands on the Southern blots) appeared to have only one insertion (Figure 3).

We located the insertion in one of the fusion defective mutants which we named J1. The insertion is in gene model Cre16.g661150. This gene is predicted to be involved in 5-deoxystrigol biosynthesis. Strigolactons are plant hormones that regulate root and shoot develop- ment in plants [37]. They are also involved in stimulating parasite germination in plant roots [38]. The role of this gene product in a unicellular alga, and the specific role, if any, in the gamete fusion process will be the subject of our future studies.

Acknowledgments - We thank Dr. Juergen Polle, Dr. Shaneen Singh, Dr. Cathreen McEntee, Dr. James Nishiura, Dr. Theodore Muth and the faculty of the biology department at Brooklyn College for helpful discussions. We thank Dr. Benjamin Ortiz for help with Southern blotting. This work was supported by National Institute of Child Health and Human Development grant \# 1R15HD048470-01A1 and PSC-CUNY grant number 62225-00-31 (both to CLF).

Disclaimer: "The contents and viewpoints expressed herein and in the materials therein reflect the personal opinion of the authors, and cannot be construed as representation of any position or opinion of Pfizer Inc. or any of its subsidiaries."

\section{References}

1. E.H. Chen, E.N. Olson, Unveiling the mechanisms of cell-cell fusion, Science, 308 (2005) 369-373.

2. G.B. Harris, H.E., Stern, D.B., Witman, The Chlamydomonas sourcebook $2^{\text {nd }}$ Ed., Academic Press, CambridgeMassachusetts, USA, 2009.

3. S.S. Merchant, S.E. Prochnik, O. Vallon, E.H. Harris, S.J. Karpowicz, G.B. Witman, A. Terry, A. Salamov, L.K. Fritz-Laylin, L. Maréchal-Drouard, W.F. Marshall, L.H. Qu, D.R. Nelson, A.A. Sanderfoot, M.H. Spalding, V.V. Kapitonov, Q. Ren, P. Ferris, E. Lindquist, H. Shapiro, S.M. Lucas, J. Grimwood, J. Schmutz, I.V. Grigoriev, D.S. Rokhsar, A.R. Grossman, P. Cardol, H. Cerutti, G. Chanfreau, C.L. Chen, V. Cognat, M.T. Croft, R. Dent, S. Dutcher, E. Fernández, H. Fukuzawa, D. González-Ballester, D. González-Halphen, A. Hallmann, M. Hanikenne, M. Hippler, W. Inwood, K. Jabbari, M. Kalanon, R. Kuras, P.A. Lefebvre, S.D. Lemaire, A. V. Lobanov, M. Lohr, A. Manuell, I. Meier, L. Mets, M. Mittag, T. Mittelmeier, J.V. Moroney, J. Moseley, C. Napoli, A.M. Nedelcu, K. Niyogi, S. V. Novoselov, I.T. Paulsen, G. Pazour, S. Purton, J.P. Ral, D. M. Riaño-Pachón, W. Riekhof, L. Rymarquis, M. Schroda, D. Stern, J. Umen, R. Willows, N. Wilson, S.L. Zimmer, J. Allmer, 
J. Balk, K. Bisova, C.J. Chen, M. Elias, K. Gendler, C. Hauser, M. R. Lamb, H. Ledford, J.C. Long, J. Minagawa, M.D. Page, J. Pan, W. Pootakham, S. Roje, A. Rose, E. Stahlberg, A.M. Terauchi, P. Yang, S. Ball, C. Bowler, C.L. Dieckmann, V.N. Gladyshev, P. Green, R. Jorgensen, S. Mayfield, B. Mueller-Roeber, S. Rajamani, R.T. Sayre, P. Brokstein, I. Dubchak, D. Goodstein, L. Hornick, Y.W. Huang, J. Jhaveri, Y. Luo, D. Martínez, W. C. A. Ngau, B. Otillar, A. Poliakov, A. Porter, L. Szajkowski, G. Werner, K. Zhou, The Chlamydomonas genome reveals the evolution of key animal and plant functions, Science, 318 (2007) 245-250.

4. R. Sager, S. Granick, Nutritional control of sexuality in Chlamydomonas reinhardi, J. Gen. Physiol., (1954) 729-742.

5. W.S. Adair, C. Hwang, U.W. Goodenough, Identification and visualization of the sexual agglutinin from the mating-type plus flagellar membrane of Chlamydomonas, Cell, 33-1 (1983) 183-193.

6. P.J. Ferris, E. Virginia Armbrust, U.W. Goodenough, Genetic structure of the mating-type locus of Chlamydomonas reinbardtii, Genetics, 160-1 (2002) 181-200.

7. P.J. Ferris, S. Waffenschmidt, J.G. Umen, H. Lin, J.H. Lee, K. Ishida, T. Kubo, J. Lau, U.W. Goodenough, Plus and minus sexual agglutinins from Chlamydomonas reinhardtii, Plant Cell, 17-2 (2005) 597-615.

8. K. Bergman, U.W. Goodenough, D.A. Goodenough, J. Jawitz, H. Martin, Gametic differentiation in Chlamydomonas Reinhardtii: II. flagellar membranes and the agglutination reaction, J. Cell Biol., 67 (1975) 606-622.

9. C.L. Forest, D.A. Goodenough, U.W. Goodenough, Flagellar membrane agglutination and sexual signaling in the conditional Gam-1 mutant of Chlamydomonas, J. Cell Biol., 79 (1978), 74-84

10. W.I. Snell, M. Buchanan, A. Clausell, Lidocaine reversibly inhibits fertilization in Chlamydomonas: A possible role for calcium in sexual signalling, J. Cell Biol., 94-3 (1982) 607-612.

11. S.M. Pasquale, U.W. Goodenough, Cyclic AMP functions as a primary sexual signal in gametes of Chlamydomonas reinhardtii, J. Cell Biol., 105-5 (1987) 2279-2292.

12. M.J. Buchanan, S.H. Imam, W.A. Eskue, W.J. Snell, Activation of the cell wall degrading protease, lysin, during sexual signalling in Chlamydomonas: the enzyme is stored as an inactive, higher relative molecular mass precursor in the periplasm, J. Cell Biol., 108 (1989) 199-207.

13. W.J. Snell, W.A. Eskue, M.J. Buchanan, Regulated secretion of a serine protease that activates an extracellular matrix-degrading metalloprotease during fertilization in Chlamydomonas, J. Cell Biol., 109 (1989) 1689-1694.

14. Y. Matsuda, T. Saito, T. Yamaguchi, H. Kawase, Cell wall lytic enzyme released by mating gametes of Chlamydomonas reinhardtii is a metalloprotease and digests the sodium perchlorate-insoluble component of cell wall, J. Biol. Chem. 260 (1985) 6373-6377.

15. U.W. Goodenough, R.L. Weiss, Gametic differentiation in Chlamydomonas reinhardtii: III. cell wall lysis and microfilament-associated mating structure activation in wild-type and mutant strains, J. Cell Biol., 67-3 (1975) 623637.

16. U.W. Goodenough, P.A. Detmers, C. Hwang, Activation for cell fusion in Chlamydomonas: analysis of wild-type gametes and nonfusing mutants, J. Cell Biol., 92 (1982) 378-386.

17. C.L. Forest, Specific contact between mating structure membranes observed in conditional fusion-defective Chlamydomonas mutants, Exp. Cell Res., 148 (1983) 143154.
18. R.L. Weiss, D.A. Goodenough, U.W. Goodenough, Membrane particle arrays associated with the basal body and with contractile vacuole secretion in Chlamydomonas, J. Cell Biol., 71-1 (1977) 133-143.

19. C.L. Forest, Genetic control of plasma membrane adhesion and fusion in Chlamydomonas gametes, J. Cell Sci., 88-5 (1987) 613-621.

20. P.J. Ferris, J.P. Woessner, U.W. Goodenough, A sex recognition glycoprotein is encoded by the plus mating-type gene fus1 of Chlamydomonas reinhardtii, Mol. Biol. Cell, 7-8 (1996) 1235-1248.

21. M.J. Misamore, S. Gupta, W.J. Snell, The Chlamydomonas Fus1 protein is present on the mating type plus fusion organelle and required for a critical membrane adhesion event during fusion with minus gametes, Mol. Biol. Cell, 14 (2003) 2530-2542.

22. T. Mori, H. Kuroiwa, T. Higashiyama, T. Kuroiwa, GENERATIVE CELL SPECIFIC 1 is essential for angiosperm fertilization, Nat. Cell Biol., 8 (2006) 64-71.

23. Y. Liu, R. Tewari, J. Ning, A.M. Blagborough, S. Garbom, J. Pei, N.V. Grishin, R.E. Steele, R.E. Sinden, W.J. Snell, O. Billker, The conserved plant sterility gene HAP2 functions after attachment of fusogenic membranes in Chlamydomonas and Plasmodium gametes, Genes Dev., 22 (2008) 1051-1068.

24. L.H. Friedman, L., Colwin, A.L., Colwin, Fine structural aspects of fertilization in Chlamydomonas reinhardi, J. Cell Sci., 3 (1968) 115-128.

25. C.L. Forest, R.K. Togasaki, Selection for conditional gametogenesis in Chlamydomonas reinhardi, Proc. Natl. Acad. Sci. U. S. A., 72 (1975) 3652-3655.

26. K.L. Kindle, High-frequency nuclear transformation of Chlamydomonas reinhardtii, Proc. Natl. Acad. Sci. USA, 87-3 (1990) 1228-1232.

27. X. Li, R. Zhang, W. Patena, S.S. Gang, S.R. Blum, N. Ivanova, R. Yue, J.M. Robertson, P.A. Lefebvre, S.T. Fitz-Gibbon, A. R. Grossman, M.C. Jonikas, An indexed, mapped mutant library enables reverse genetics studies of biological processes in Chlamydomonas reinhardtii, Plant Cell, 28 (2016) 367-387.

28. S. Lumbreras, V., Stevens, D.R., Purton, Efficient foreign gene expression in Chlamydomonas reinhardtii mediated by an endogenous intron, Plant J., 14 (1998) 441-447.

29. D.R. Stevens, J.D. Rochaix, S. Purton, The bacterial phleomycin resistance gene ble as a dominant selectable marker in Chlamydomonas, Mol. Gen. Genet., 251 (1996) 23-30.

30. R. Sager, Genetic systems in Chlamydomonas., Science, 1323438 (1960) 1459-1465.

31. C.L. Forest, Mutational disruption of the $9+2$ structure of the axoneme of Chlamydomonas flagella, J. Cell Sci., 61 (1983) 423-436.

32. F.M. Ausubel, R. Brent, R.E. Kingston, D.D. Moore, J.G. Seidman, J.A. Smith, K. Struhl, C.J. Wiley, R.D. Allison, M. Bittner, S. Blackshaw, Current protocols in molecular biology, John Wiley and Sons, Hoboken-New Jersey, USA, 2003.

33. R.M. Dent, C.M. Haglund, B.L. Chin, M.C. Kobayashi, K.K. Niyogi, Functional genomics of eukaryotic photosynthesis using insertional mutagenesis of Chlamydomonas reinhardtii, Plant Physiol., 137 (2005) 545-556. 
332 M. Aksoy et al. / Hacettepe J. Biol. \& Chem., 2021, 49 (3), 321-332

34. D. González-Ballester, A. De Montaigu, A. Galván, E. Fernández, Restriction enzyme site-directed amplification PCR: A tool to identify regions flanking a marker DNA, Anal. Biochem., 340 (2005) 330-335.

35. B. Cenkci, J.L. Petersen, G.D. Small, REX1 a novel gene required for DNA repair, J. Biol. Chem., 278-25 (2003) 22574 22577.

36. M. Aksoy, W. Pootakham, A.R. Grossman, Critical function of a Chlamydomonas reinhardtii putative polyphosphate polymerase subunit during nutrient deprivation, Plant Cell, 26 (2014) 4214-4229.
37. M. Iseki, K. Shida, K. Kuwabara, T. Wakabayashi, M. Mizutani, H. Takikawa, Y. Sugimoto, Evidence for species-dependent biosynthetic pathways for converting carlactone to strigolactones in plants, J. Exp. Bot., 69-9 (2018) 2305-2518.

38. D. Gobena, M. Shimels, P.J. Rich, C. Ruyter-Spira, H. Bouwmeester, S. Kanuganti, T. Mengiste, G. Ejeta, Mutation in sorghum LOW GERMINATION STIMULANT 1 alters strigolactones and causes Striga resistance, Proc. Natl. Acad. Sci. USA., 114 (2017) 4471-4476. 